\title{
Implementation of a Web System to Improve the Evaluation System of an Institute in Lima
}

\author{
Franco Manrique jaime, Laberiano Andrade-Arenas \\ Facultad de Ciencias e Ingeniería \\ Universidad de Ciencias y Humanidades \\ Lima, Perú
}

\begin{abstract}
In Peru and the world, millions of students saw their education interrupted caused by the problems brought by the COVID-19 virus, due to this many educational entities began to adopt learning platforms and web systems so that the teaching process is not affected, having to comply with all the guidelines and requirements of the institution to solve any academic difficulty. That is why in the present work the implementation of a web system was proposed for the improvement of the qualification and evaluation processes of an institution using the scrum methodology since it is an agile framework that is based on empiricism and offers adaptation and flexibility in the projects. For the software development, the open source language PHP was used since it is more adapted to these web systems, Mysql was also used, which is a database manager for relational databases. The results of this research was the correct implementation of this system to the educational institution, verifying the absence of errors and the improvement of the processes involved so that the institution can provide students with an adequate learning process.
\end{abstract}

Keywords-COVID-19; evaluation; learning platform; scrum; web system

\section{INTRODUCTION}

Today the percentage of educational institutions that adopt a virtual teaching platform is increasing, this due in large part to confinement due to pandemic, creating a change in the global teaching process, Currently, virtual teaching is defined as the development of the learning process through the use of digital and information tools, where the student and the teacher are not physically present in the same room. Nowadays, many students went from the face-to-face to the virtual, bringing with them new problems to solve. This new reality brought new methods and ways to have a better understanding of the educational process in universities and institutions [1]. The change in the way of teaching in institutions due to the COVID-19 pandemic forced many educational entities to adopt virtual teaching systems since, due to the circumstances, classes and online interaction are considered the best option that can be adapted to this new form of teaching and that complies with the confinement regulations issued by the governments of different parts of the planet. These web systems provide all kinds of tools so that students can learn from home without having to return to face-to-face classes or be in contact with other people [2]. Although most institutions have some type or form of software to process, retrieve, store information, today these systems need to be increasingly accurate with a minimum error percentage because these systems must provide students and teachers tools and resources quickly and safely [3]. Some platforms have certain limitations that prevent covering all the needs of the institutions, these institutions, by not having the required modules and by not satisfying all the needs of the different areas involved, are not able to provide the information necessary for decision-making in an academic setting. This affects students because the student, guided by the teacher, makes use of the different tools and resources offered by these web systems to access important information and develop activities that help the student consolidate knowledge and develop skills.

For all the aforementioned and with the purpose of solving these academic difficulties of the Institute of Sciences and $\mathrm{Hu}-$ manities (ICH), through technology, specifically in the design and development of a web system, the following question was asked: What measure will a web system of qualification and evaluation improve the process of monitoring and control of information in the Institution of Sciences and Humanities?

Due to the lack of adherence of some processes with the requirements of the institution, this can harm its decisionmaking, affecting the learning and teaching process. This work offers a proposal, solution to the problems of the educational institution through the web system that will optimize resources by improving the level of satisfaction of those involved as teachers and students, in addition, the web system will accelerate the evaluation and qualification processes of the institution making them more efficient and with fewer errors.

The objective of this project is to seek to improve through a web system the qualification process and results of mock admission exams managed by the directorate of systems and communications of the $\mathrm{ICH}$.

In Section II, a review of the literature was carried out; in Section III the methodology; as well as in Section IV the case study; in Section V the result and discussion; and finally in Section VI Conclusion and future work.

\section{LITERATURE REVIEW}

The project consists of designing and implementing a web system for the improvement of the qualification process and results of the mock admission exam of an educational institution to provide a better experience for students in addition to processing and analyzing the grades of students to obtain information performance and progress. A large percentage of educational institutions in Peru use learning platforms for virtual teaching and with the presence of COVID-19 and 
quarantine this percentage is increasing even more, so knowing these tools today is essential for institutions educational.

Regarding virtual education due to pandemic, there are different positions such as that of the author Eduardo Norman Acevedo [4] which says that due to the current situation referring to the health situation caused by COVID-19, educational institutions had to change the teaching processes to adapt to this new way of teaching and learning, being mainly evaluative, ethical, sociological, pedagogical changes. On the other hand, María Laura Picón [5] indicates that millions of students were affected by this problem, having to adapt to these new tools in order to receive online classes, however, how prepared were not only the institutions but also the students? This change in teaching brought with it new problems for students such as lack of technological resources, lack of internet in rural areas, students with disabilities, etc. This need to apply virtual teaching revealed the inequality of training for the use of these technologies and the lack of knowledge by both teachers and students. Based on the above, Javier Arturo Hall López [6] mentions that virtual teaching also brought problems on the physical health of students, due to sedentary lifestyle and lack of exercise make students more likely to suffer from weight problems, this is a challenge pedagogical in teaching and in the way of teaching classes, which has to propose better teaching methodologies so that the student can be guided in the development of their motor skills. At the same time, these education platforms are increasingly being adopted by more education centers, as explained by D. Benta [7] in his report, where he mentions that tools such as Moodle help motivate students and those involved in solving collaborative and individual tasks.

About traditional teaching, Jacinto Joaquín Vertíz Osores [8] indicates, that the traditional form of evaluation used in universities has been attributed almost entirely to the criteria of the professors, who guided the process towards the quantification of the indicators expressed in their links and that they are supposed to reflect the level of progress of the students. In retrospect, this traditional way of evaluating students to measure learning and level of knowledge has remained frozen in time and does not appear to have changed in the last 50 years [9]. However, at the current stage, where the educational scheme is not the same, with means of remote interaction, in this new scheme, teachers ask university authorities about evaluation methods, consult strategies and propose methods, being fully aware of the shortcomings of the new interaction scenario. On the other hand, Olga V. Bondarenko [10] points out that, in a virtual educational environment, the nature of the interaction of those involved in learning (a student, a group of students or a teacher) changes fundamentally. The term study is not used because it is interpreted as a cognitive activity of students who, under the guidance of a teacher, master skills, knowledge. The involvement of students in a virtual education environment means that the teacher must change his role from mentor and director to tutor, facilitator and moderator [11]. The teacher strives to help students find an individual educational path. Currently and due to the pandemic, there are more and more modern students living in a media environment where the use of computers, internet resources and the use of mobile devices is part of their day to day. It is for this point that virtual educational environments are now a reality that basically deals with an information space for the interaction of students in an educational process generated by communication and information.

The advantages of a virtual educational environment include: flexibility, economic efficiency, interactivity, mobility. In this context, M'Balia Thomas [12] indicates that the change to virtual classes due to the pandemic forced teacher educators to rethink them, they do not normally teach or design the content of online courses. Thus, as the global pandemic grows and accelerates a continued rise in e-learning, teacher educators must reexamine what it means to be equitable, responsive and inclusive to the individual needs of a diverse set of pre-service teachers and take into account consideration of collective professional needs. With regard to systems related to virtual education, there are various authors such as Cristian Enrique Mejía and Mariano Enrique Álava [13] who developed a grade registration system for a school with 60 years of service that lacked a virtual education environment, it is for this reason that there was a deficient management of the file with important content such as qualifications, enrollment, etc., and that they were solved by this software that optimized said processes. It also allows to reduce the response time of processes and improve the teaching process and thus increase the satisfaction of the students. It is clear that these web systems helped learning from home, institutions such as those mentioned had to adapt to these new platforms so that this training process is not interrupted and although not all have the means to take this type of non-face-to-face classes, a large percentage were able to continue with their training process.

In summary, the authors analyzed in their research show that there is still a need to carry out digital transformation in institutions to make the implementation of the evaluation system more effective and efficient. The investigation that will be carried out is to see how to optimize with the implementation of the web page in an effective way in its processes.

\section{METhODOLOGY}

\section{A. Methodology SCRUM:}

The Scrum methodology is a framework that addresses complex problems (ver Fig. 1), where a lot of ambiguity can be observed; in addition, it helps to promote creativity and productivity of teams because events tend to generate creative tension in the team [14]. In addition to this always tends to seek to deliver products of the highest value. both scrum and other methodologies allow the team to make the most of resources and time, however this does not mean that this framework does not have disadvantages. Scrum is based on empiricism, rather, learning as you go, it is for this reason that the incremental interactive life cycle is usually perfect for this framework [15]. In Scrum there are roles which are the Scrum Master, the Scrum team and the Product Owner [16]. This agile framework or framework created in the 90's by Schwaber and Sutherland. It follows an approach that is based on evidence, starting from the premise that problems can never be defined or understood in their entirety, which is why organizations and companies have to focus on getting trained teams to respond to change.

The characteristics that most identify this framework [17], are the following:

- Flexibility and adaptation. 
- Return on investment.

- $\quad$ Risk mitigation.

- An always motivated team.

- An alignment between the client and the team Productivity and quality.

- $\quad$ This intensified work entails a high prediction of times since the speed and performance of the equipment is known.

- $\quad$ The method of work and continuous review produces a higher quality of the software.

\section{B. Scrum Activities}

1) Sprint Planning: This is a meeting that has to be held at the beginning of a sprint and it is necessary for the entire team to participate [15]. This task planning is divided into two main parts:

First part of the meeting. This has a Timebox of 4 hours.

- This is where the client shows the list of requirements to the manager, and specifies the priority requirements.

- Then the list is analyzed, doubts are resolved and it is agreed which requirements will be a priority in each iteration.

Second part of the meeting: As in the first part, here a timebox is made that can last a maximum of 4 hours. Here the iteration is analyzed and planned, and proceeds to create tactics that will help you meet the objective.

- Team members can assign themselves tasks to perform.

- The effort to perform each task will be calculated.

2) Sprint: In Scrum we have iterations, these iterations in Scrum are called sprint, each one of the sprint delivers value to the end users or to those who are solving a particular problem, this value grows with each iteration.

3) Scrum Daily Meeting: In these meetings, what is sought is the transfer of relevant value together with the collaboration of team members to improve productivity. Here each member reviews everyone's work to be able to make the necessary changes to finish and comply with the sprint.

4) Sprint Retrospective: This is the event where all members of the Team evaluate and inspect themselves, this in order to improve during the next Sprint. Here we analyze how they are working, why they achieve or not the objective in which they are failing.

5) Sprint Review: This event takes place at the end of each sprint. During this informal meeting the increase is reviewed, rather, what was done during the sprint and if there were changes, the Product Backlog is analyzed.
6) Team Roles: This methodology is made up of three main roles. Each of these roles has different responsibilities and must act differently [18].

- Scrum Master: He is an expert in scrum, he is a facilitator coach, he trains and removes the impediments that can be seen in daily meetings.

- Product Owner: It is the empowered person, who establishes the product backlog, is responsible for the return on investment, is represented by a single person and works on the product vision.

- Development team: All the members are called developments and they are full time in what they are doing, it is a multidisciplinary team that is self-managed and estimates its own time, it is a small team and it is recommended that it be from 3 to 9 people.

7) Product Backlog: This is a list with elements, these elements are called PBI (Product backlog item), this artifact is not only composed of user stories, in the scrum guide they mention that other values such as needs, requirements, cases of uses, defects etc. This stack is ordered, being the first in the stack the ones that generate the greatest value to the business or the highest value to the end users and therefore the last in the stack is what generates the least value or little value compared to the first pbi. Scrum, being iterative and agile, allows new PBIs to be entered into the backlog that may arise as we advance in the project, that is why it is said that the product backlog is emergent, which means that we can be adding new things according to the product or according to the project I need it.

8) Burndown Chart: This is a graph that shows over time the speed and the time in which the objectives and requirements are being completed. Provides a better overview of the team's pace of progress in order to predict whether the team will complete the work in the estimated times.

9) ScrumTaskboard: This is a board with the tasks to be done. And be organized in such a way that the objectives are assigned the necessary tasks to finish it, usually post-its are used, and they change position according to their status. To differentiate the tasks that each member is performing, smaller colored stickers are used.

10)Disadvantages of Scrum: Scrum is not perfect. Therefore, we can mention some of the most important disadvantages of Scrum:

At the time of starting with Scrum, the whole team must know very well its principles and theoretical framework, also that there be knowledge of the Scrum roles or this could alter the functions and tasks. To a large extent, much of the success of the project will depend on the level of knowledge of the scrum master (rather than on the innovation, creativity or quality of the inputs). If for some reason some task is not completed, other tasks may be compromised due to that sometimes these can be related, this can generate delays in the sprints or the delivery of an unsatisfactory value.

The following figure shows the stages of this methodology graphically, showing the order of the activities [14]. 


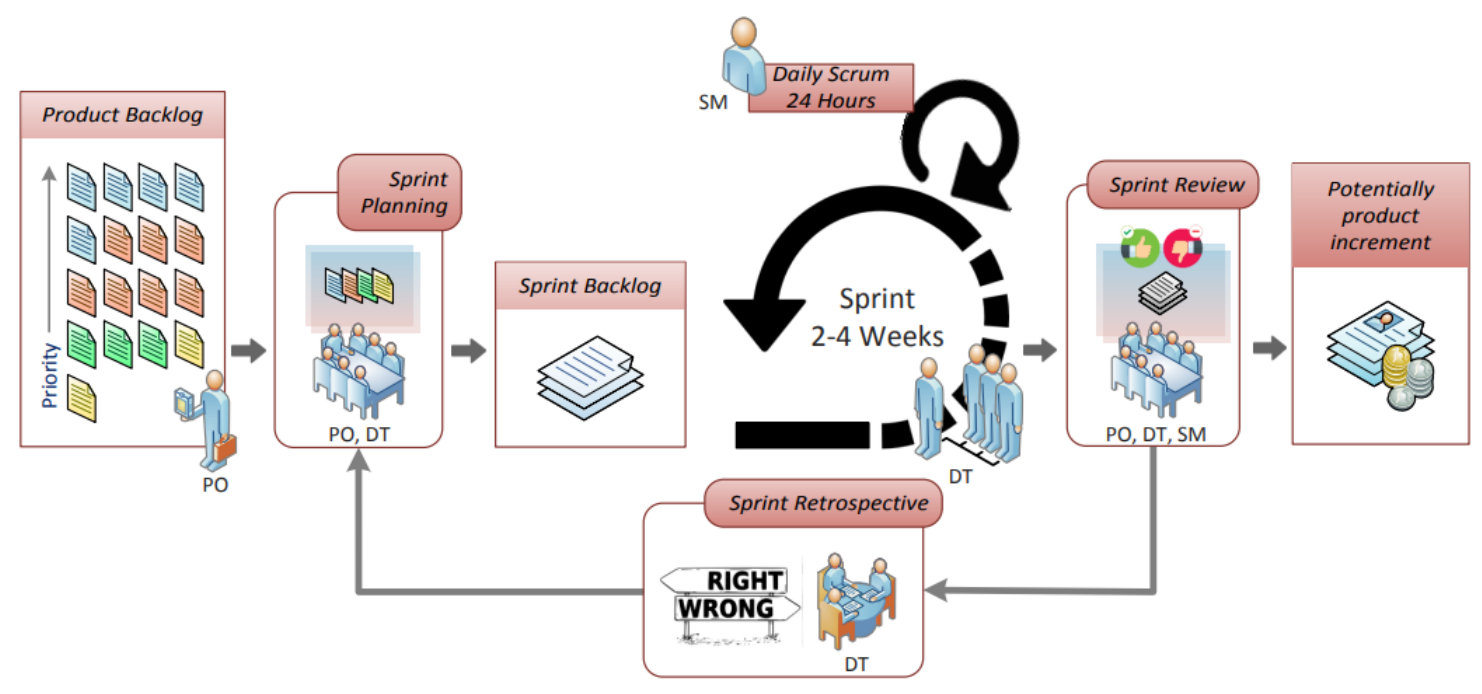

Fig. 1. The Phases of the Scrum Methodology.

\section{CASE Study}

\section{A. Initiation Phase}

1) User Story: In Table I, was create user stories, that are general and informal explanations of the characteristics of the software, these are from the point of view of the end user, in our case we identified 22.

2) Product Backlog: In the product backlog basically organize the list of tasks was carried out for the project. In Table II, we show the priority or rather the degree of importance and to which module it belongs, in this work we were able to identify 4 modules.

\section{B. Planning and Estimation Phase}

1) Sprint Backlog: In Table III, Table IV, Table V are the objectives, the elements chosen in the product backlog to be completed in each sprint, in our project we identify three sprints.

In Table VI, the weighting that was used is detailed in the following.

\section{2) User Story Sprint 1:}

a) Exam management module 1: In this module 7 user stories were created for the creation, deletion, modification and list of exams, likewise a time can be assigned for taking the test, also for greater convenience the exam can be copied.Table VII and Table VIII show the windows of this module.

b) Exam management module 2: In this module 4 user stories were created for the management of sections, questions and courses, this window can only be used by administrator type users.In the part of the questions because they are associated with an exam, the questions cannot be eliminated directly, what is done is a logical elimination. Table IX and Table $\mathrm{X}$ show the windows of this module.
TABLE I. USER STORY

\begin{tabular}{|l|l|}
\hline ID & \multicolumn{1}{|c|}{ USER STORY } \\
\hline 1 & As an administrator I need to view the windows to configure the exams. \\
\hline 2 & As Administrator I need to register an answer for each question. \\
\hline 3 & As Administrator I need to register the sections to place the questions. \\
\hline 4 & As Administrator I need to record the time for each area. \\
\hline 5 & $\begin{array}{l}\text { As Administrator I need to register the number of questions for each } \\
\text { area. }\end{array}$ \\
\hline 6 & As Administrator I need to record the total time for all sections. \\
\hline 7 & $\begin{array}{l}\text { As Administrator I need to register the total number of questions to } \\
\text { set limits. }\end{array}$ \\
\hline 8 & As Administrator I need to register the courses for each section. \\
\hline 9 & $\begin{array}{l}\text { As Administrator I need to have reports by dates to indicate the day } \\
\text { the exam was taken. }\end{array}$ \\
\hline 10 & $\begin{array}{l}\text { As Administrator I need a merit report by specialty to see your } \\
\text { information. }\end{array}$ \\
\hline 11 & As Administrator I need a general merit report to see your information. \\
\hline 12 & $\begin{array}{l}\text { As an administrator I need to edit the number of questions per area } \\
\text { to update the data. }\end{array}$ \\
\hline 13 & As Administrator list the sections to view the existing information. \\
\hline 14 & As Administrator I need to have a course report to see your information \\
\hline 15 & $\begin{array}{l}\text { As Administrator I need to view the exam model to see the changes } \\
\text { made. }\end{array}$ \\
\hline 16 & As a student, I need to take the exam for the evaluation. \\
\hline 17 & As a Student I need to visualize the windows for taking exams. \\
\hline 18 & As a Student I need a report card to see my results. \\
\hline 19 & As a Student I need to finish the test to choose a new section. \\
\hline 20 & $\begin{array}{l}\text { As a Student I need to see the detailed result, showing which ones } \\
\text { were incorrect, which ones were correct and which ones I did not } \\
\text { answer. }\end{array}$ \\
\hline 21 & As a Student I need to finish the exam even if time is not over yet. \\
\hline
\end{tabular}

3) User Story Sprint 2: In this module the administrators will be able to observe the progress of the students in the courses as well as view the reports of the students by date, year, course and type of exam. These data can later be analyzed to obtain statistical tables as a result. Table XI and Table XII show the windows of this module. 
TABLE II. PRODUCT BACKLOG

\begin{tabular}{|c|c|c|c|c|}
\hline ID & USER STORY & Priority & Sprint & MODULE \\
\hline 1 & $\begin{array}{l}\text { As an administrator I need to } \\
\text { view the windows to config- } \\
\text { ure the exams. }\end{array}$ & High & \multirow{7}{*}{1} & \multirow{3}{*}{$\begin{array}{l}\text { Exam manage- } \\
\text { ment } 1\end{array}$} \\
\hline 2 & $\begin{array}{l}\text { As Administrator I need to } \\
\text { register an answer for each } \\
\text { question. }\end{array}$ & High & & \\
\hline 3 & $\begin{array}{l}\text { As Administrator I need to } \\
\text { register the sections to place } \\
\text { the questions. }\end{array}$ & High & & \\
\hline 4 & $\begin{array}{l}\text { As Administrator I need to } \\
\text { record the time for each area. }\end{array}$ & High & & \multirow{4}{*}{$\begin{array}{l}\text { Exam manage- } \\
\text { ment } 2\end{array}$} \\
\hline 5 & $\begin{array}{l}\text { As Administrator I need to } \\
\text { register the number of ques- } \\
\text { tions for each area. }\end{array}$ & Half & & \\
\hline 6 & $\begin{array}{l}\text { As Administrator I need to } \\
\text { record the total time for all } \\
\text { sections. }\end{array}$ & High & & \\
\hline 7 & $\begin{array}{l}\text { As Administrator I need to } \\
\text { register the total number of } \\
\text { questions to set limits. }\end{array}$ & Half & & \\
\hline 8 & $\begin{array}{l}\text { As Administrator I need to } \\
\text { register the courses for each } \\
\text { section. }\end{array}$ & High & \multirow{4}{*}{2} & \multirow{4}{*}{ Results } \\
\hline 9 & $\begin{array}{l}\text { As Administrator I need to } \\
\text { have reports by dates to in- } \\
\text { dicate the day the exam was } \\
\text { taken. }\end{array}$ & Low & & \\
\hline 10 & $\begin{array}{l}\text { As Administrator I need a } \\
\text { merit report by specialty to } \\
\text { see your information. }\end{array}$ & High & & \\
\hline 11 & $\begin{array}{l}\text { As Administrator I need a } \\
\text { general merit report to see } \\
\text { your information. }\end{array}$ & High & & \\
\hline 12 & $\begin{array}{l}\text { As a Student I need to take the } \\
\text { exam for the evaluation. }\end{array}$ & High & \multirow{5}{*}{3} & \multirow{5}{*}{ Student } \\
\hline 13 & $\begin{array}{l}\text { As a Student I need to visu- } \\
\text { alize the windows for taking } \\
\text { exams. }\end{array}$ & High & & \\
\hline 14 & $\begin{array}{l}\text { As a Student I need a report } \\
\text { card to see my results. }\end{array}$ & Half & & \\
\hline 15 & $\begin{array}{l}\text { As a Student I need to finish } \\
\text { the test to choose a new sec- } \\
\text { tion. }\end{array}$ & High & & \\
\hline 16 & $\begin{array}{l}\text { As a Student I need to be able } \\
\text { to enter an exam to view their } \\
\text { schedules. }\end{array}$ & High & & \\
\hline
\end{tabular}

TABLE III. SPRINT BACKLOG FROM SPRINT 1

\begin{tabular}{|c|c|c|c|}
\hline \multirow[t]{2}{*}{ PRIORITY } & CHORES & DIFFICULTY & \multirow{2}{*}{$\begin{array}{c}\text { HOURS } \\
11\end{array}$} \\
\hline & \multicolumn{2}{|l|}{ SPRINT 1 } & \\
\hline 1 & $\begin{array}{l}\text { As an administrator I need to view the } \\
\text { windows to configure the exams. }\end{array}$ & 5 & 3 \\
\hline 2 & $\begin{array}{l}\text { As Administrator I need to register an } \\
\text { answer for each question. }\end{array}$ & 3 & 2 \\
\hline 3 & $\begin{array}{l}\text { As Administrator I need to register the } \\
\text { sections to place the questions. }\end{array}$ & 3 & 1 \\
\hline 4 & $\begin{array}{l}\text { As Administrator I need to record the } \\
\text { time for each area. }\end{array}$ & 2 & 1 \\
\hline 5 & $\begin{array}{l}\text { As Administrator I need to register the } \\
\text { number of questions for each area. }\end{array}$ & 2 & 2 \\
\hline 6 & $\begin{array}{l}\text { As Administrator I need to record the } \\
\text { total time for all sections. }\end{array}$ & 2 & 1 \\
\hline 7 & $\begin{array}{l}\text { As Administrator I need to register the } \\
\text { total number of questions to set limits. }\end{array}$ & 2 & 1 \\
\hline
\end{tabular}

4) User Story Sprint 3: In this module, students will be able to take the exams and see their results.To take an exam, the date and time have to be appropriate in addition to having previously chosen an exam.After the student completes the test, the scores and the exam are calculated It ends without the option of taking it again. To enter this module the student must be previously registered in the system.Students who did not solve the test are scheduled another date and their score
TABLE IV. SPRINT BACKLOG FROM SPRINT 2

\begin{tabular}{|c|l|c|c|}
\hline \multirow{2}{*}{ PRIORITY } & \multicolumn{1}{|c|}{ CHORES } & DIFFICULTY & HOURS \\
\cline { 2 - 4 } & \multicolumn{1}{|c|}{ SPRINT 2 } & 10 \\
\hline 1 & $\begin{array}{l}\text { As Administrator I need to register the } \\
\text { courses for each section. }\end{array}$ & 4 & 3 \\
\hline 2 & $\begin{array}{l}\text { As Administrator I need to have reports } \\
\text { by dates to indicate the day the exam } \\
\text { was taken. }\end{array}$ & 4 & 2 \\
\hline 3 & $\begin{array}{l}\text { As Administrator I need a merit report } \\
\text { by specialty to see your information. }\end{array}$ & 3 & 1 \\
\hline 4 & $\begin{array}{l}\text { As Administrator I need a general merit } \\
\text { report to see your information. }\end{array}$ & 3 & 1 \\
\hline 5 & $\begin{array}{l}\text { As Administrator I need to register the } \\
\text { number of questions for each area. }\end{array}$ & 2 & \\
\hline
\end{tabular}

TABLE V. SPRINT BACKLOG FROM SPRINT 3

\begin{tabular}{|c|l|c|c|}
\hline \multirow{2}{*}{ PRIORITY } & \multicolumn{1}{|c|}{ CHORES } & DIFFICULTY & HOURS \\
\cline { 2 - 4 } & \multicolumn{1}{|c|}{ SPRINT 3 } & 3 \\
\hline 1 & $\begin{array}{l}\text { As an administrator I need to edit the } \\
\text { number of questions per area to update } \\
\text { the data. }\end{array}$ & 3 & 3 \\
\hline 2 & $\begin{array}{l}\text { As Administrator list the sections to } \\
\text { view the existing information. }\end{array}$ & 3 & 2 \\
\hline 3 & $\begin{array}{l}\text { As Administrator I need to have a course } \\
\text { report to see your information. }\end{array}$ & 3 & 1 \\
\hline 4 & $\begin{array}{l}\text { As Administrator I need to view the } \\
\text { exam model to see the changes made. }\end{array}$ & 3 & 3 \\
\hline 5 & $\begin{array}{l}\text { As Administrator I need to manage the } \\
\text { scores by section. }\end{array}$ & 4 & 3 \\
\hline
\end{tabular}

is modified, in addition the student's information is saved and processed for future reports Table XIII and Table XIV show the windows of this module.

5) Design Pattern MVC: The model view controller pattern $(\mathrm{mvc})$ is a pattern that separates the data into three different modules, each fulfilling a function different. This software architecture pattern applies code reuse, facilitating software development and maintenance as shown in Fig. 2 [14]. In Fig. 3 , we can see the order of the folders following this pattern. This model can be used to develop desktop applications or mobile applications in this way creating the mobile version of the system will be much easier.

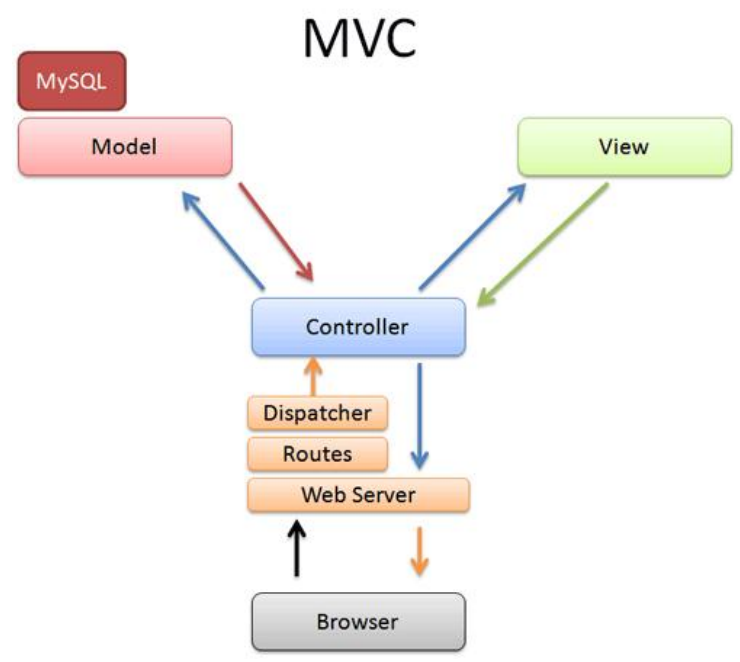

Fig. 2. MVC Operation. 
TABLE VI. WEIGHTING CRITERION

\begin{tabular}{|c|l|}
\hline DIFFICULTY & WEIGHT \\
\hline Easy & 1 \\
\hline Little Easy & 2 \\
\hline Regular & 3 \\
\hline Little difficult & 4 \\
\hline Hard & 5 \\
\hline
\end{tabular}

TABLE VII. USER STORY-EXAM MANAGEMENT

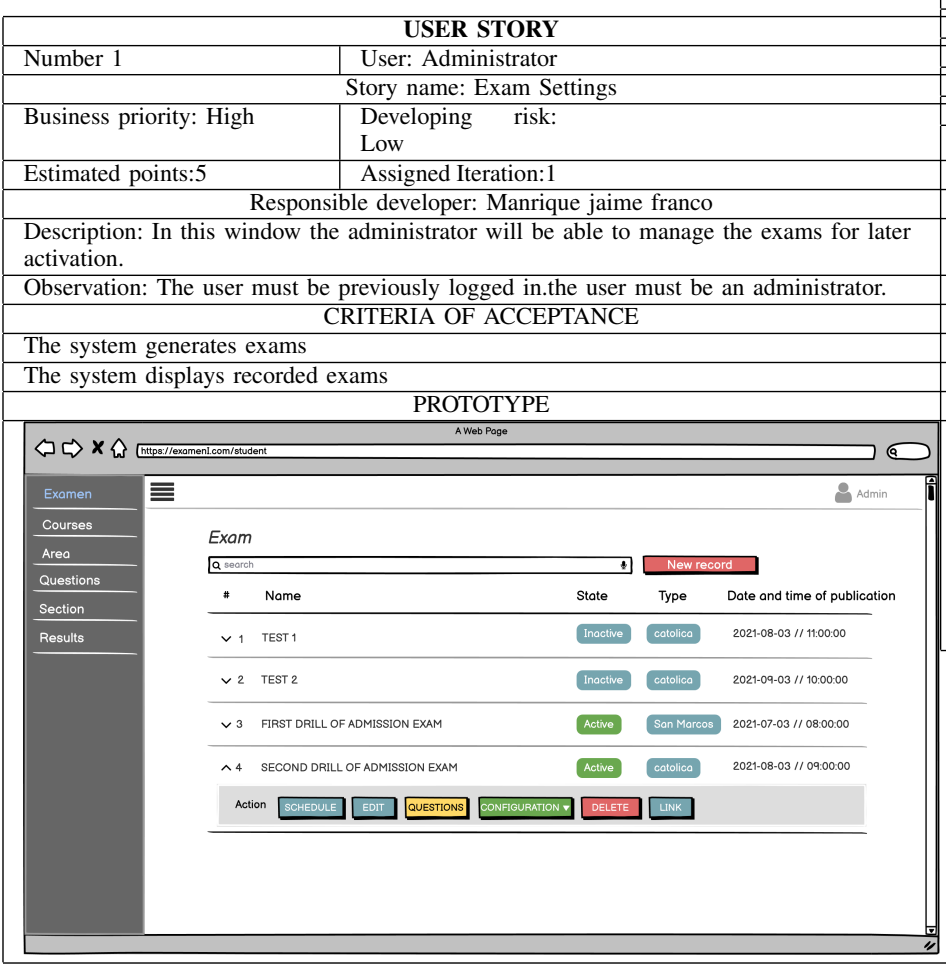

6) Database Model: Fig. 4 shows the diagram of the database.The diagram has 15 tables; the main ones being the exam table where the exams with the corresponding questions are recorded and the configuration table which relates the students with the grades.

The DB was developed in MYSQL since it is a database manager that best adapts to web systems as well as being free and easy to use. This manager is compatible with Windows and Linux operating systems.

The database was developed using Navicat which is a tool for the development of BDs and that allows managing multiple databases.This tool was chosen for its compatibility with the manager and for its easy handling.

\section{RESUlt AND Discussion}

\section{A. Sprint 1 Testing and Review}

1) Exam: In Fig. 5, the exam window is shown where the exams will be shown, registered, deleted and modified, also it will be possible to create schedules and register questions. For the administrator's convenience, it will also be possible to duplicate the exam including the questions.

2) Section: Fig. 6 shows the section window where sections will be displayed, registered, deleted and modified. To register a section it is necessary to specify its name.
TABLE VIII. USER STORY-SECTION MANAGEMENT

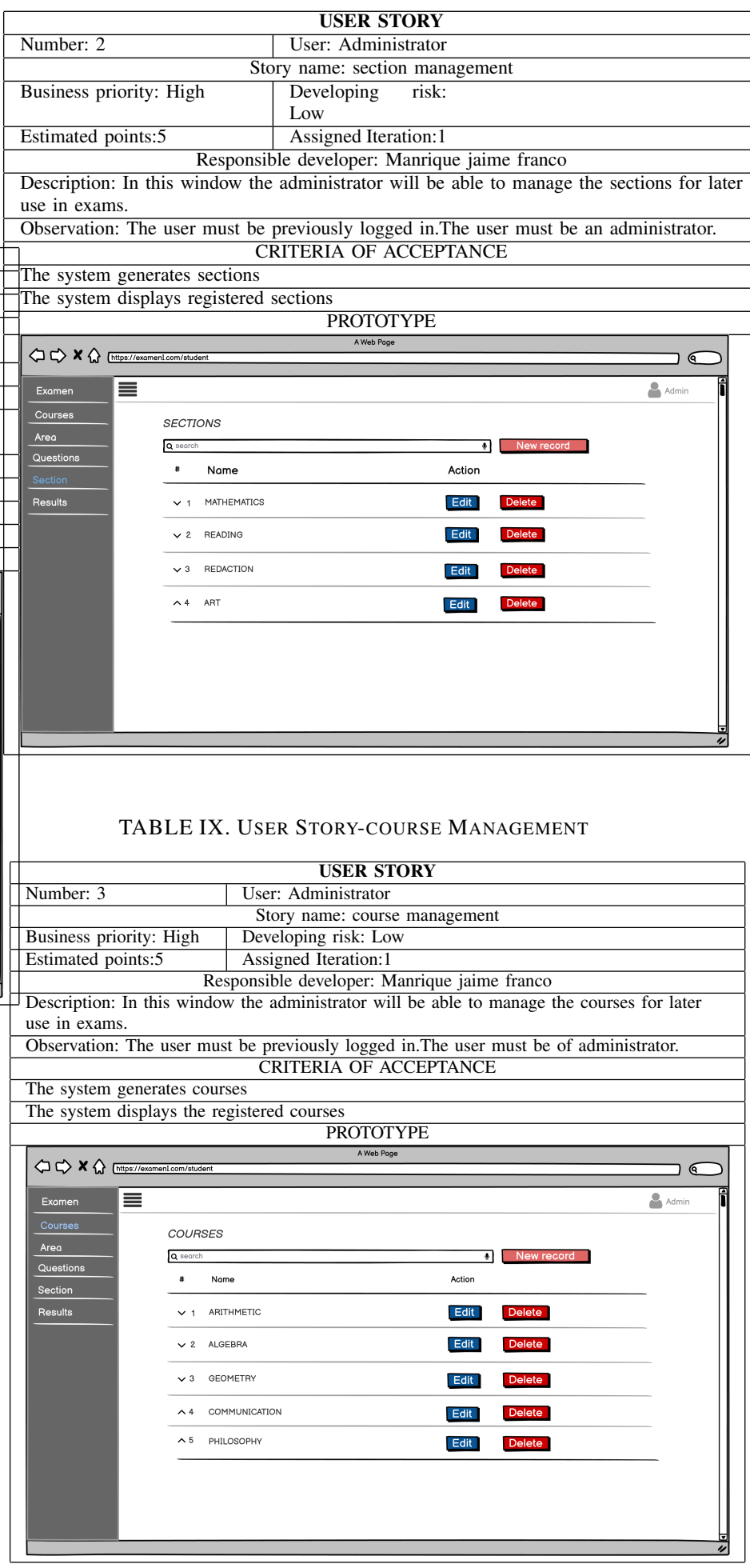

3) Course: Fig. 7 shows the course window where the courses will be displayed, registered, deleted and modified.To register a course it is necessary to specify the section to which it belongs.

4) Area: In Fig. 8, the window of areas is shown which for security reasons cannot be modified, for now the only way 
TABLE X. USER STORY-QUESTION MANAGEMENT

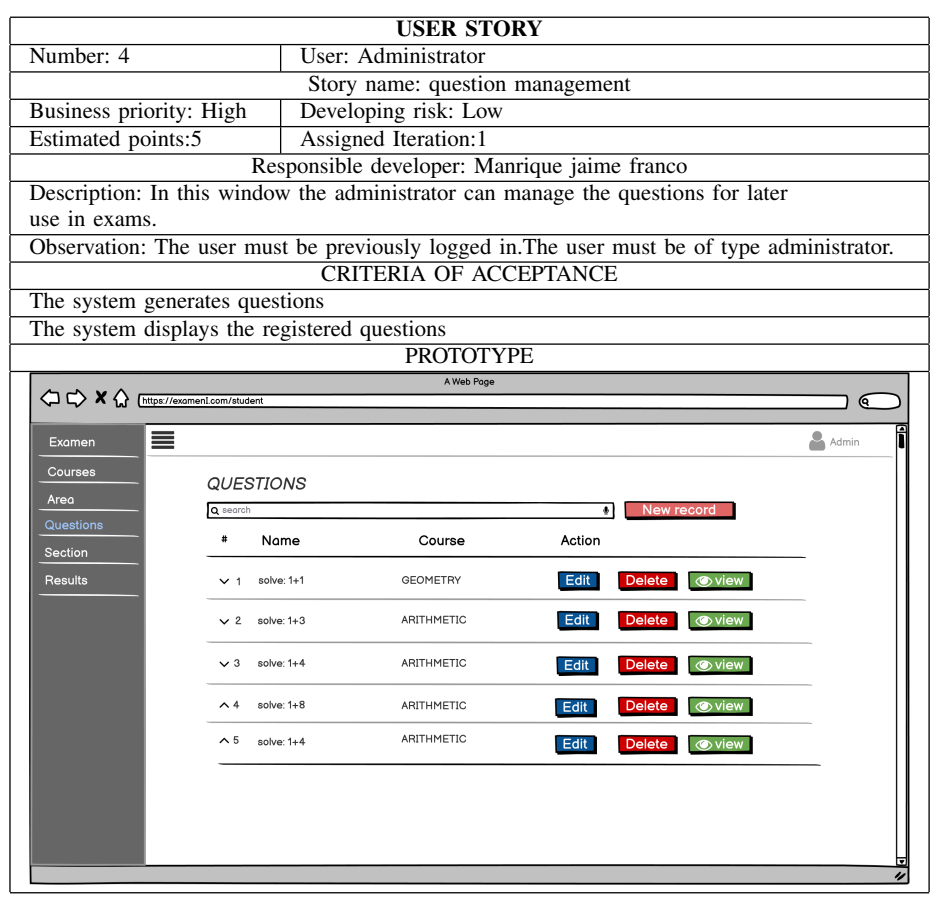

TABLE XI. USER STORY-STUDENT REPORT

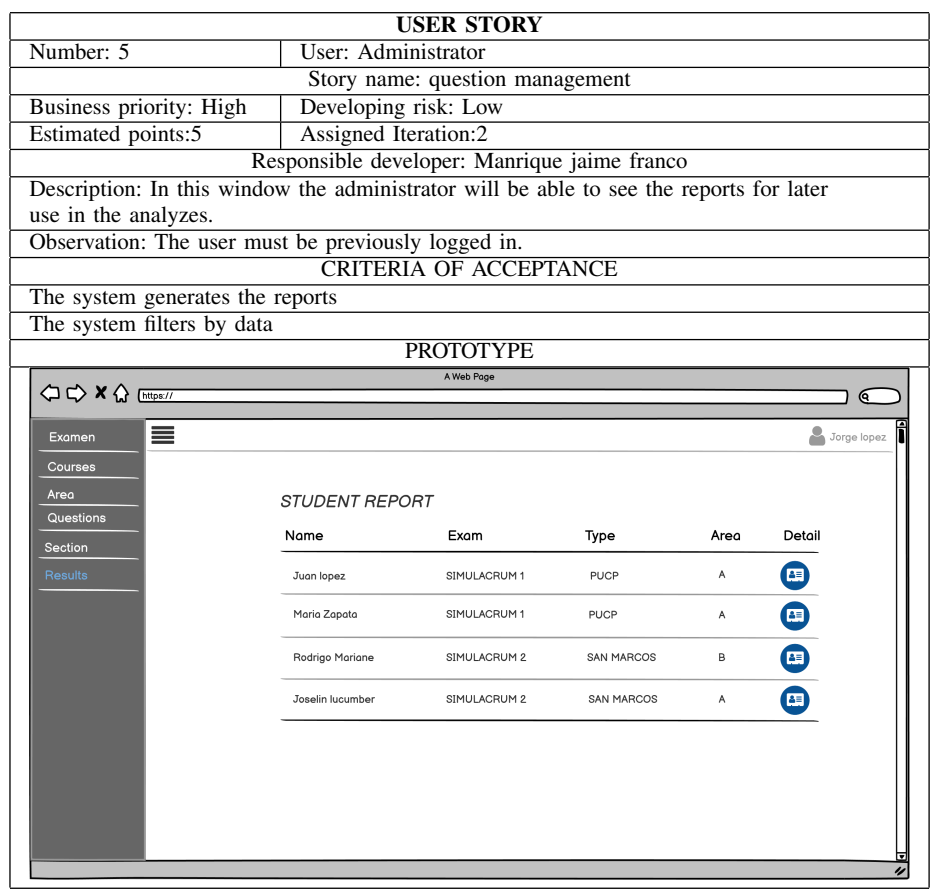

to add or delete areas is through the database.

5) Question: Fig. 9 shows the question window where the entered questions will be displayed, registered, deleted and modified.

6) Alternatives: Fig. 10 shows the alternatives window where the alternatives entered per question will be shown, registered, eliminated and modified.
TABLE XII. USER STORY-REPORT OF MERITS

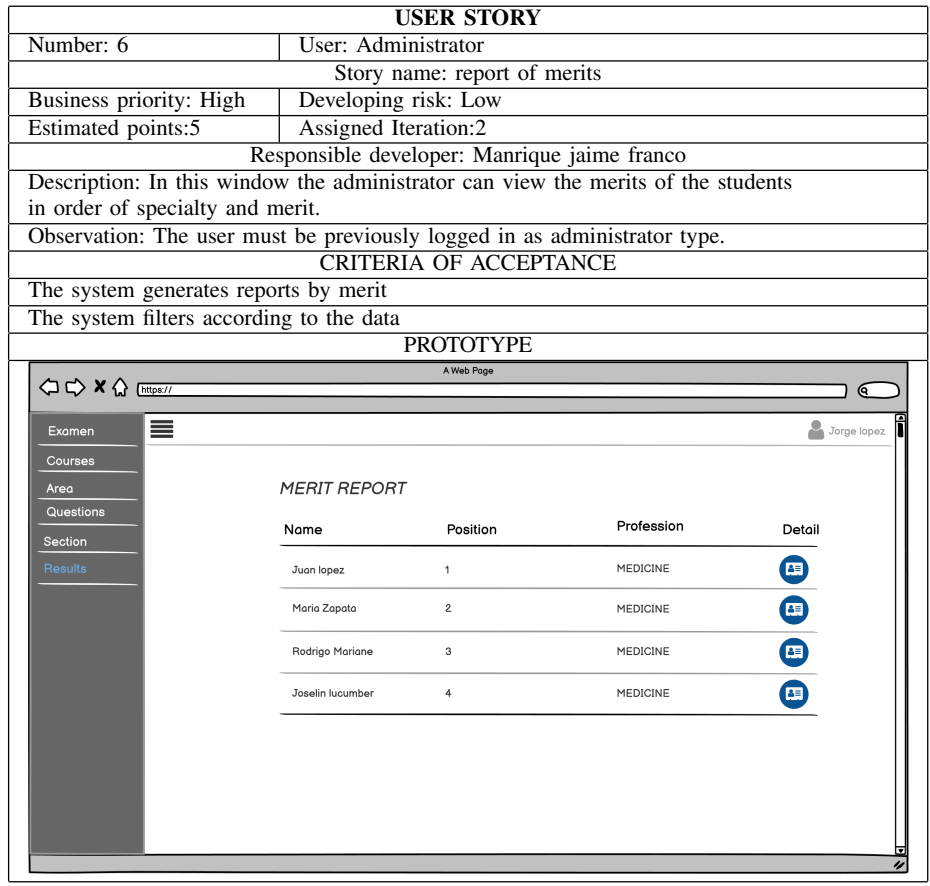

TABLE XIII. USER StORY-EXAM TIME TABLES

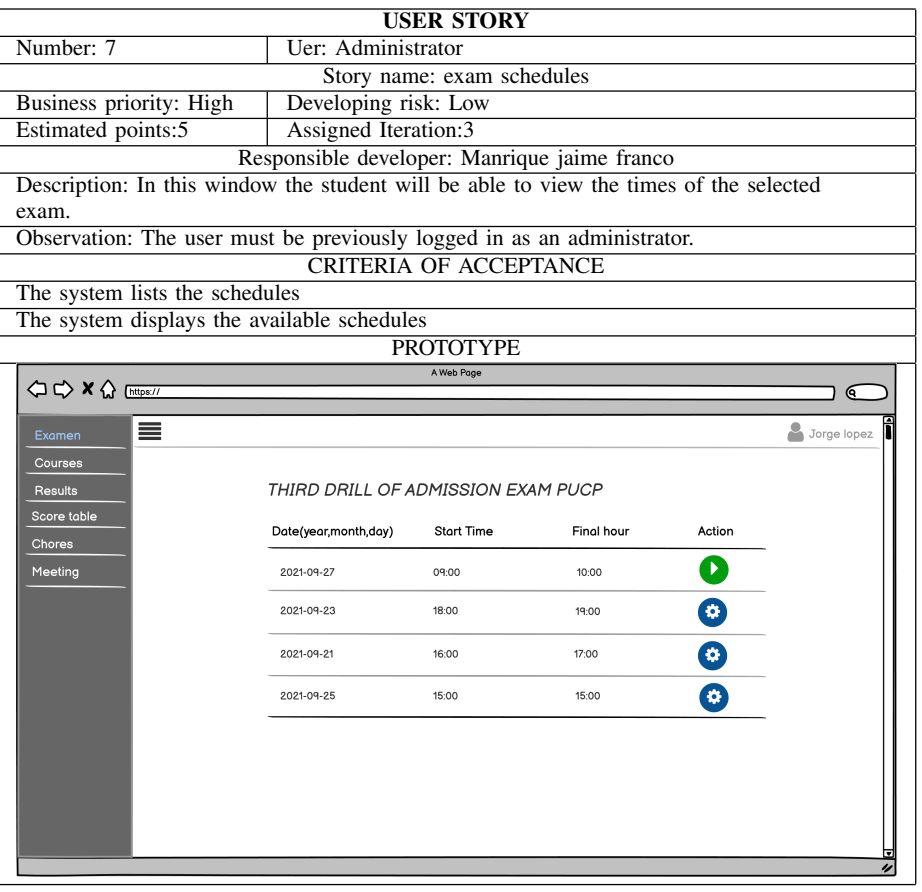

\section{B. Sprint 2 Testing and Review}

1) Exam Results: Fig. 11 shows the results exam window where the list of exams taken will be shown, clicking on one will show the students who took said exam.

2) Student results: Fig. 12 shows the results window by exam where the list of students who took the selected exam will be shown, showing their grade and date, also as the 
TABLE XIV. USER STORY-VIEW TEST

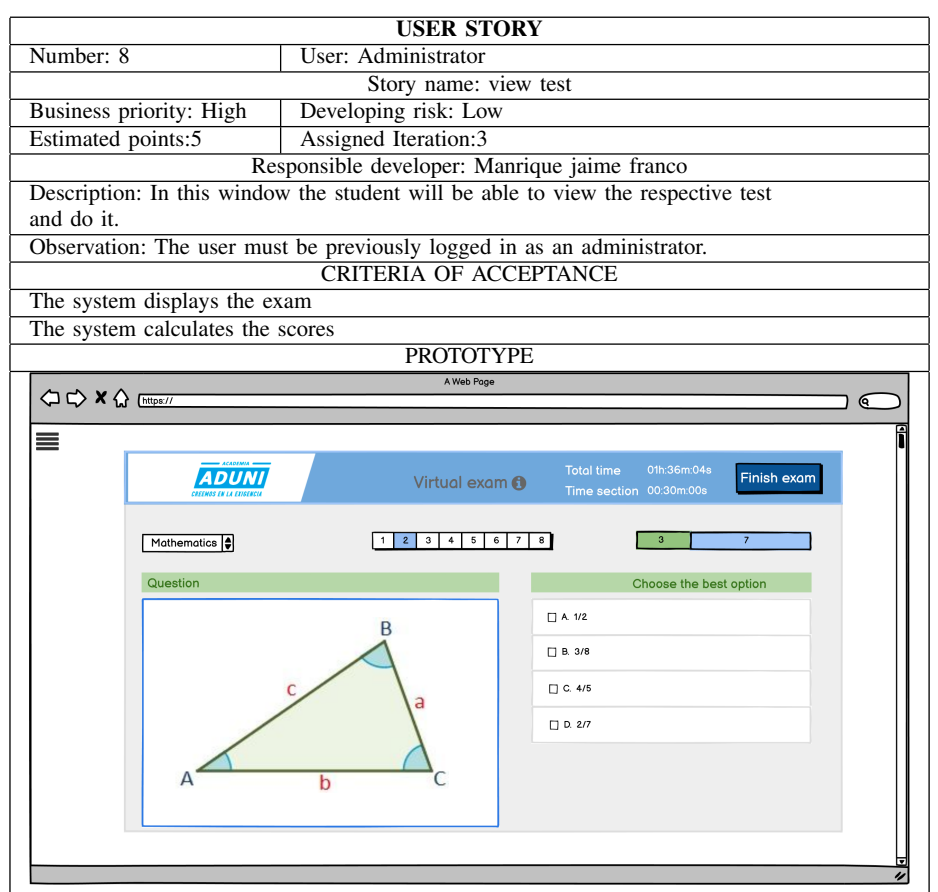

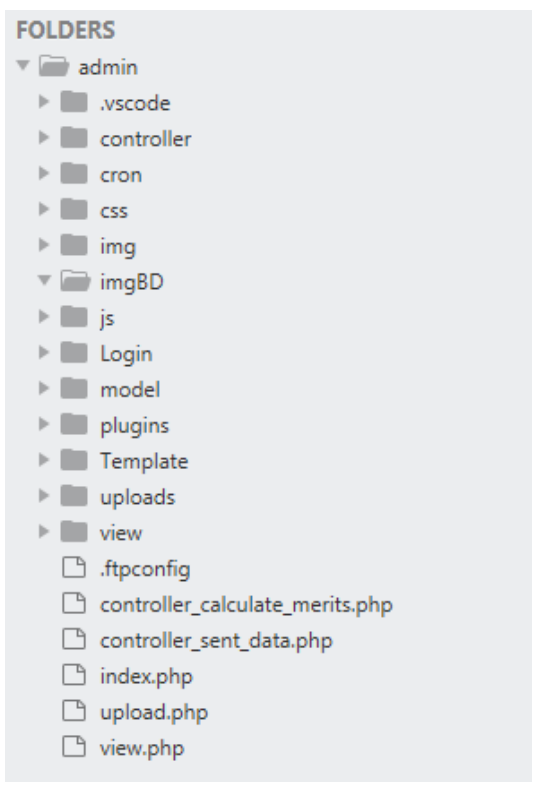

Fig. 3. MVC Order.

database handles a large number of records, a search engine was added to find the student quickly.

\section{Sprint 3 Testing and Review}

1) Exam: Fig. 13 shows the time list window where the student will view the available schedules, if the student has already completed the test, the buttons will be blocked preventing entry.

2) Test: Fig. 14 shows the exam window where the student will take the virtual practice, the practice has a general time limit and by section, if the student finishes before they can press the button finish exam to finish it, once finished a message will be displayed thanking you for your participation and will redirect you to the schedule list window.

3) Student results: Fig. 15 shows the results window where the student will view the scores obtained from the test in addition to the position by general merit and by specialty, he will also be able to view all the test questions along with the correct answer and the alternative marked by the student.If the student does not take the test, a new date is scheduled, however the merits will not be shown.

The notes are calculated from time to time through files called CRON which are responsible for executing the code every 40 minutes, modifying the time in which the CRON will be executed is done manually. It is due to this file that if a student takes the exam after the scheduled date, it will have no merit and only their score will be recorded.

According to the author [2], his studies were based on the use of web systems by students remotely, where the advantages of using the platform in times of pandemic stand out, which is consistent with our research since it was also carried out in the same pandemic context where the Authorities show support for the investigation as there is satisfaction on their part.

\section{CONCLUSion AND Future Work}

According to the requirements and needs of the Institution of Sciences and Humanities, a web system was implemented for the improvement of evaluation and qualification processes, which consists of three modules which are the exam, results and student management module. The response time of the system was also reduced when displaying the exam and scoring the tests, in the same way it was possible to create a friendly interface for both students and administrative staff, thus improving the creation and taking of virtual evaluations.It is suggested that future work be implemented a mobile application that allows complementing the institute's evaluation system.

\section{REFERENCES}

[1] N. Bocanegra and M. Navarro, "Evaluación Virtual: Un recurso para potenciar la Autorregulación y el Aprendizaje," Redie.Mx, p. 220, 2019. [Online]. Available: http://www.redie.mx/librosyrevistas/libros/evaluacion virtual.pdf

[2] F. d. R. A. Gordón, "From face-to-face learning to virtual learning in pandemic times," Estudios Pedagogicos, vol. 46, no. 3, pp. 213-223, 2020.

[3] I. Gómez-Arteta and F. Escobar-Mamani, "Educaciòn virtual en tiempos de pandemia: incremento de la desigualdad social en el Perú Virtual education in times of Pandemic : increasing social inequality in Perú," Chakiñan, Revista De Ciencias Sociales Y Humanidades, 2021. [Online]. Available: https://chakinan.unach.edu.ec /index.php/chakinan/article/view/553

[4] E. N. Acevedo and C. E. Daza-orozco, "construction of content for virtual edication : lockdown' s content for virtual education : lockdown , s," pp. 0-4, 2020.

[5] P. Abrahamsson, O. Salo, J. Ronkainen, and J. Warsta, "Agile software development methods: Review and analysis," CoRR, vol. abs/1709.0, 2017.

[6] P. Srinivasan, Editor, 2020, no. June.

[7] R. J. Wilcha, "Effectiveness of virtual medical teaching during the COVID-19 crisis: Systematic review," JMIR Medical Education, vol. 6, no. 2, pp. 1-16, 2020.

[8] J. J. V. Osores, R. R. C. Flores, R. I. Vértiz-Osores, G. L. V. Ochoa, and A. A. Romero, "Virtual university education in the context of the health 


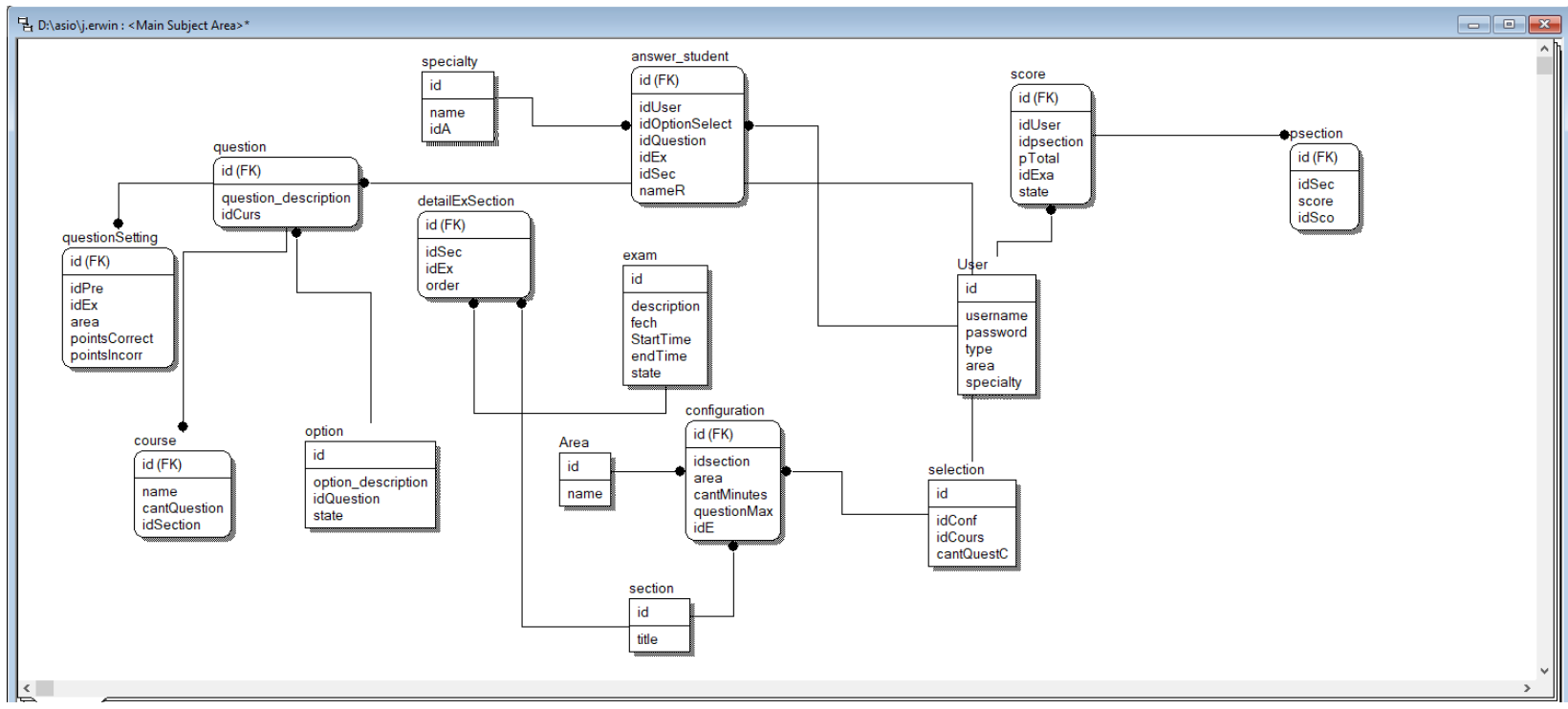

Fig. 4. Database Model.

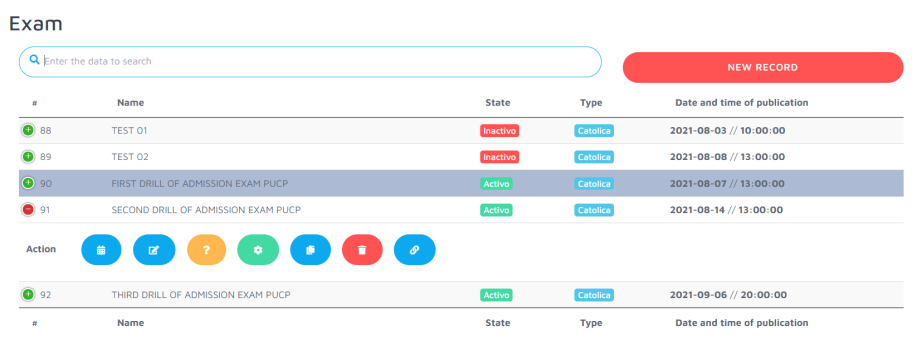

Fig. 5. Exam Management.
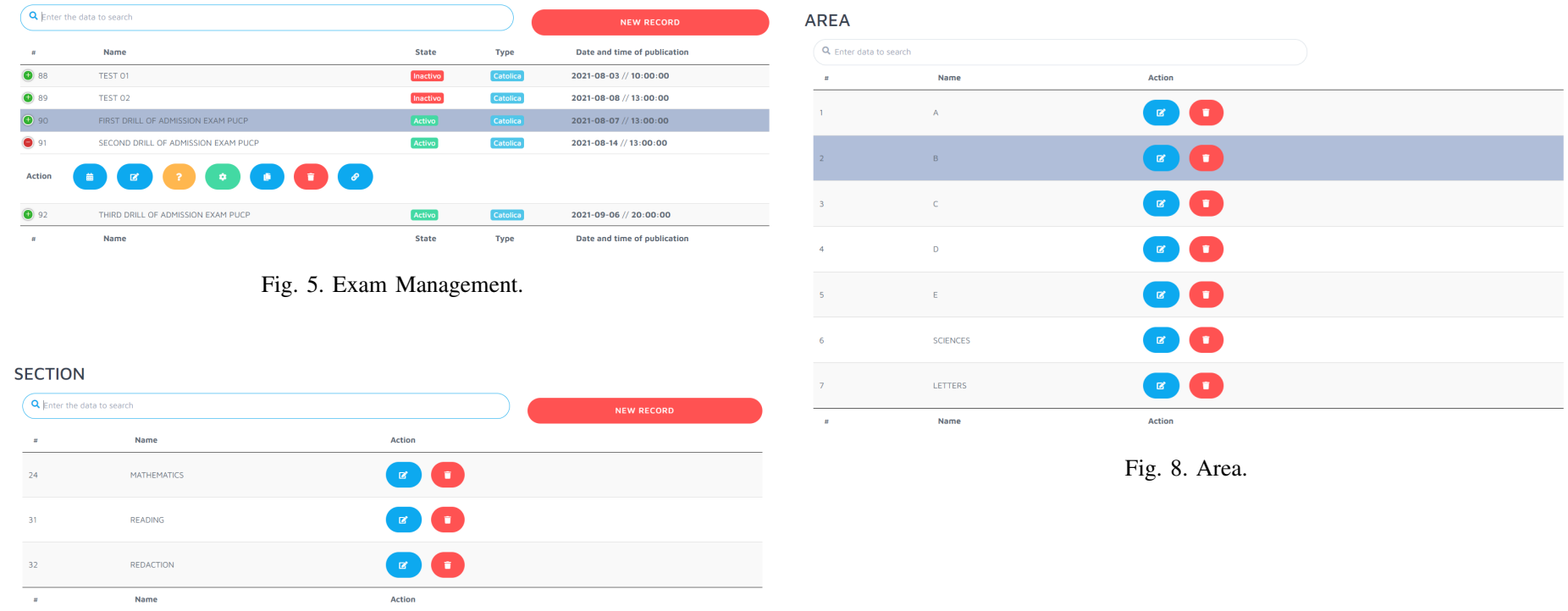

Fig. 6. Section Management.
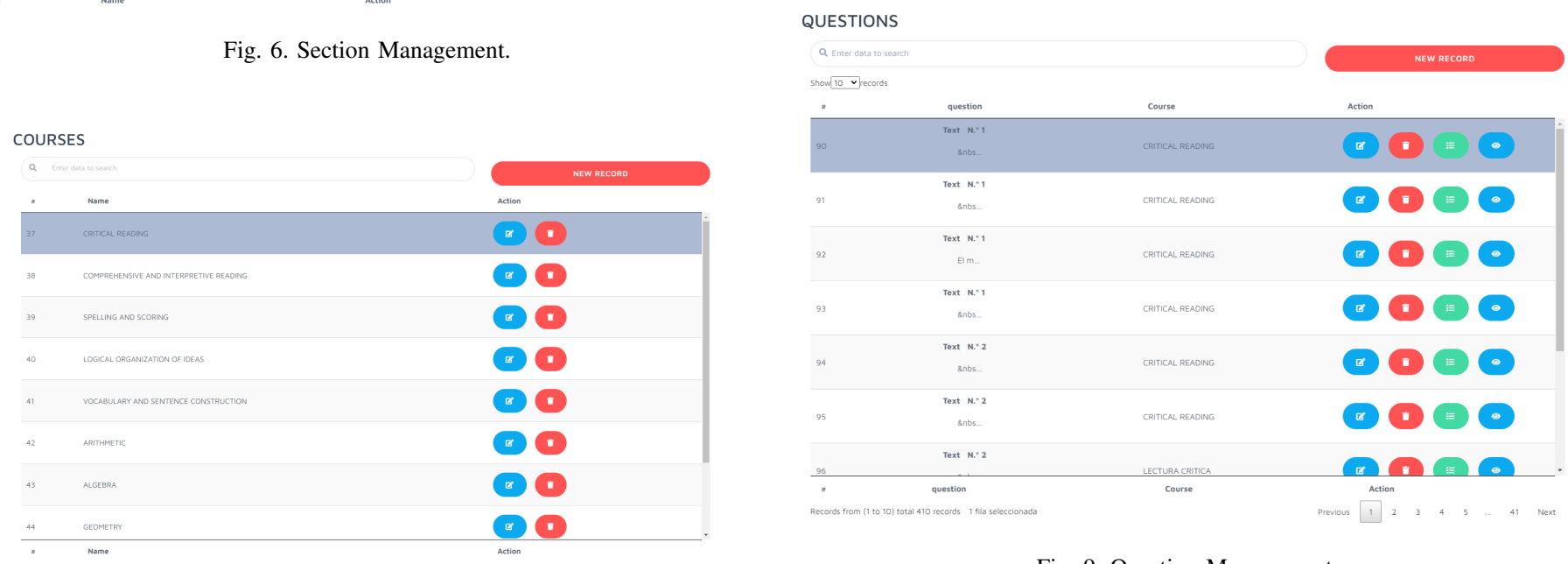

Fig. 7. Course Management.

Fig. 9. Question Management. 


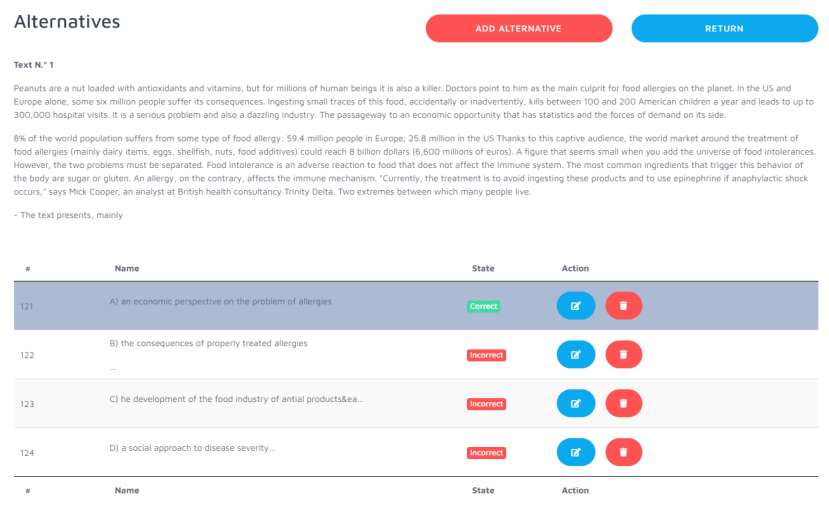

Fig. 10. Alternative Management.

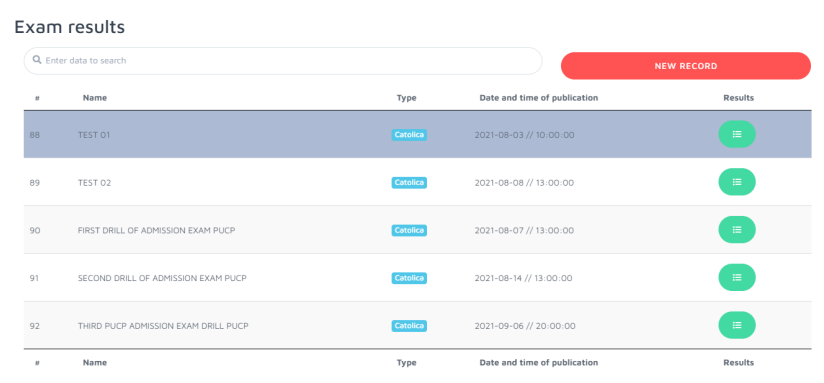

Fig. 11. Exam Results Window.

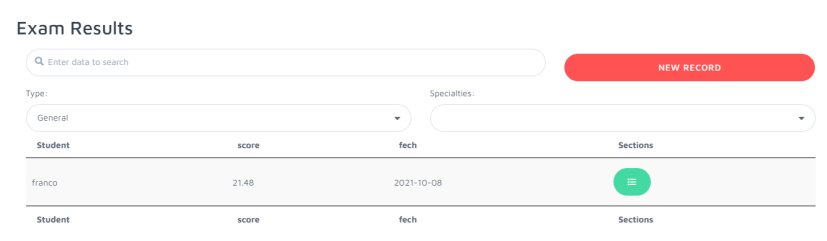

Fig. 12. Student Results.

THIRD DRILL OF ADMISSION EXAM PUCP

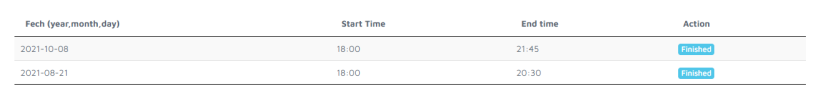

Fig. 13. Hours Available.

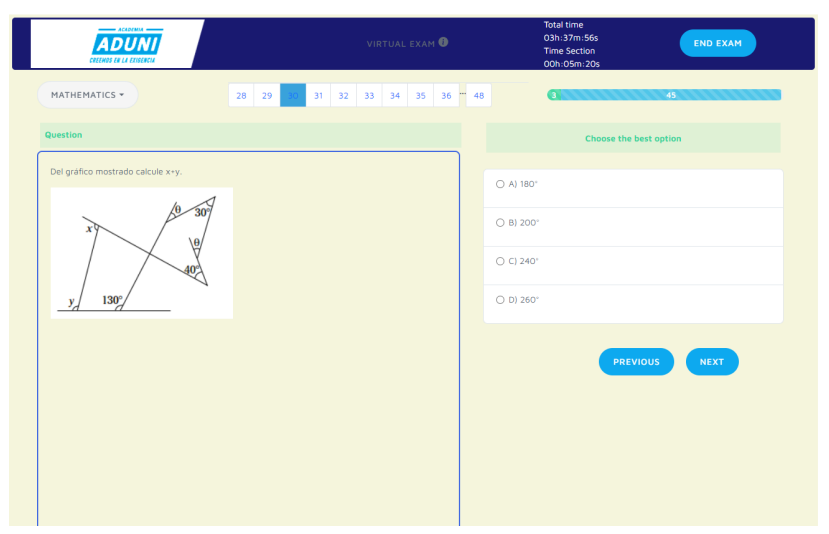

Fig. 14. Virtual Test.

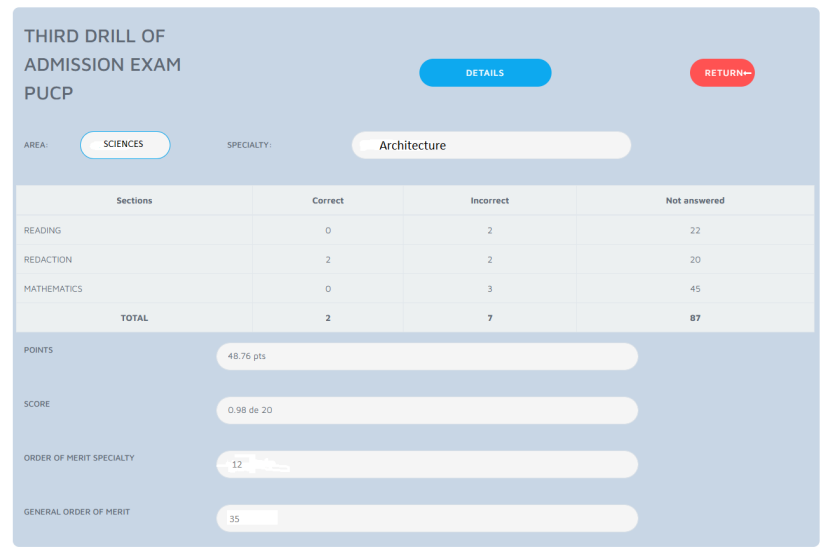

Fig. 15. Results.

emergency due to COVID-19: Challenges in the evaluation processes," International Journal of Early Childhood Special Education, vol. 12, no. 1, pp. 467-477, 2020.

[9] Z. I. Almarzooq, M. Lopes, and A. Kochar, "Virtual Learning During the COVID-19 Pandemic: A Disruptive Technology in Graduate Medical Education," Journal of the American College of Cardiology, vol. 75, no. 20 , pp. 2635-2638, 2020.

[10] O. V. Bondarenko, O. V. Pakhomova, and W. Lewoniewski, "The didactic potential of virtual information educational environment as a tool of geography students training," CEUR Workshop Proceedings, vol. 2547, pp. 13-23, 2020.

[11] A. N. Grigorev, V. V. Fadeeva, A. C. Kodoeva, N. V. Bichan, and I. V. Dzyadevich, "Using the grade-rating system assessing the knowledge when teaching informational and legal disciplines in universities of law enforcement agencies," SHS Web of Conferences, vol. 108, p. 05004, 2021.

[12] M. Thomas, "Virtual Teaching in the Time of COVID-19: Rethinking Our weird Pedagogical Commitments to Teacher Education," Frontiers in Education, vol. 5, no. December, 2020.

[13] S. K. Shahzad, J. Hussain, N. Sadaf, S. Sarwat, U. Ghani, and R. Saleem, "Impact of Virtual Teaching on ESL Learners39; Attitudes under Covid19 Circumstances at Post Graduate Level in Pakistan," English Language Teaching, vol. 13, no. 9, p. 1, 2020.

[14] D. A. Barcelos Bica and C. A. G. D. Silva, "Learning process of agile scrum methodology with lego blocks in interactive academic games: Viewpoint of students," Revista Iberoamericana de Tecnologias del Aprendizaje, vol. 15, no. 2, pp. 95-104, 2020.

[15] J. Vogelzang, W. F. Admiraal, and J. H. Van Driel, "Effects of Scrum methodology on students' critical scientific literacy: The case of Green Chemistry," Chemistry Education Research and Practice, vol. 21, no. 3, pp. 940-952, 2020.

[16] A. Tupia-Astoray and L. Andrade-Arenas, "Implementation of an e-commerce system for the automation and improvement of commercial management at a business level," International Journal of Advanced Computer Science and Applications, vol. 12, no. 1, 2021. [Online]. Available: http://dx.doi.org/10.14569/IJACSA.2021.0120177

[17] P. N. Astya, Galgotias University. School of Computing Science and Engineering, Institute of Electrical and Electronics Engineers. Uttar Pradesh Section, Institute of Electrical and Electronics Engineers. Uttar Pradesh Section. SP/C Joint Chapter, and Institute of Electrical and Electronics Engineers, "Proceeding, International Conference on Computing, Communication and Automation (ICCCA 2016) : 29-30 April, 2016," pp. 867-872, 2016.

[18] V. Gomero-Fanny, A. R. Bengy, and L. Andrade-Arenas, "Prototype of web system for organizations dedicated to e-commerce under the scrum methodology," International Journal of Advanced Computer Science and Applications, vol. 12, no. 1, 2021. [Online]. Available: http://dx.doi.org/10.14569/IJACSA.2021.0120152 